\title{
A mini review fermentation and preservation: role of Lactic Acid Bacteria
}

\begin{abstract}
The main focal point of this review is the investigation of the roles of LAB (Lactic Acid Bacteria) in food preservation and milk fermentation. The LAB is composed of Gram-Positive, cocci, rods, non-spore forming and is producing lactic acid at the time of fermentation process of carbohydrates. LAB is used from ancient times for fermentation of food and dairy items. But nowadays it is the main attention phenomenon for scientific world. LAB has unique properties and has the ability to produce Bacteriocins, which is anti-microbial compound. LAB is also used for health medical treatment and is also used as substitute for chemicals in the process of food preservation. In the recent years, the scientific reports show that LAB has many positive health effects. LAB is used as starter culture in milk fermentation. $\mathrm{LAB}$ also gives flavor to yogurt and produces acid in milk fermentation and works as preservative agent. Due to dynamic characteristics of LAB it is important to educate the world about LAB vital roles in food industry and its hygiene properties.
\end{abstract}

Keywords: milk, preservation, fermentation, lactic acid bacteria
Volume 6 Issue 5 - 2018

\author{
Aizhan Rakhmanova,' Zaid Ashiq Khan, ${ }^{2}$ \\ Kamran Shah ${ }^{3}$ \\ 'College of Food Science, Northwest Agriculture and Forestry \\ University, China \\ ${ }^{2}$ College of Agriculture Economics and Management, Northwest \\ Agriculture and Forestry University, China \\ ${ }^{3}$ College of Horticulture, Northwest Agriculture and Forestry \\ University, China
} Correspondence: Aizhan Rakhmanova, College of Food
Science, Northwest Agriculture and Forestry University, Yangling,
Shaanxi, China, Tel +86|329909/332,

Email aizhan020994@gmail.com

Received: August 31, 2018 | Published: September 10, 2018

\section{Introduction}

LAB (Lactic Acid Bacteria) has very big importance industrially and is used for milk preservation, fermentation and cheese, yogurt, and kefir and butter milk. Species from the Gram Positive bacteria group are used which includes the genera Lactobacillus, Leuconostoc, Lactococcus, Streptococcus and Pediococcus. They can be recognized from their fermentative ability and they are enriching nutrients, improving organoleptic attributes, improving food safety and also provide health benefits. ${ }^{1-4}$

Milk is highly perishable in characteristics and LAB is used to prolong its shelf life with milk fermentation. It also helps to preserve the nutritional components of milk. The fermentation of milk with the usage of LAB is produced high quality milk products and they have high organoleptic attributes. Recently a variety of products are developed from fermented milk to facilitate health sector, like to prevent toxins, which are produced by pathogens and some spoilage bacteria. ${ }^{1,3,5,6}$

LAB presence in the milk fermentation is immunizing starter cultures. While milk is also known as natural habitats of LAB. ${ }^{7,8}$ Milk fermentation technology is generally cost effective and relatively simple. LAB is used on the other hand as important starter cultures in large scale under controlled conditions. While comparing with the products under natural fermentation, LAB has potential starter cultures which reduces and dominate the microorganism's diversity in fermented milk products. Using LAB in preservation and milk fermentation improves the quality and milk palatability.

The main objective of this review paper is to facilitate the reader with the summarized data. Most of aspects related to LAB functions in preservation and milk fermentation are reviewed. The articles and researches already done on health properties of $\mathrm{LAB}$, preservative and antimicrobial property of LAB by various researchers were also combined and reviewed.

\section{Milk fermentation (functions of Lactic Acid Bacteria)}

LAB (Lactic Acid Bacteria) is predominating of micro flora in milk products, in dairy products many species are involved. ${ }^{9}$ LAB can be divided into two groups in dairy fermentation according their growth optimum, Mesophilic LAB have 20 to $30^{\circ} \mathrm{C}$ growth temperature and thermophilic have growth optimum from 30 to $45^{\circ} \mathrm{C}$. Western and Northern European countries products have Mesophilic bacteria, while sub-tropical countries products have thermophilic bacteria. During the fermentation of glucose, the LAB is divided into two groups, Homofermentative and Heterofermentative LAB. Homofermentative bacteria's are Pediococcus, Lactococcus and Streptococcus, lactic acid is sole product produced in the fermentation of glucose. While, Heterofermentative bacteria's are Leuconostoc and Weissella produce $\mathrm{CO}_{2}$, lactate and ethanol from glucose. ${ }^{10-12}$

Along with milk products LAB is used extensively in food fermentation. $\mathrm{LAB}$ has proteolytic activity and is very important to produce flavor compound in end product. ${ }^{13}$ For the growth of microorganisms, proteolytic system in LAB is very important. It involves casein utilization in LAB cells; in fermented milk products they produce organoleptic properties. ${ }^{13,14}$

LAB plays vital role in fermentation of milk and milk products. Various LAB strains are used as starter cultures in milk industry as shown in Table 1. These starter cultures were collected from sequence activity of LAB and then they were isolated, selected and confirmed. LAB has most important property to acidify milk and gives texture and flavor because of converting milk protein. ${ }^{15}$ Fermented milk has characteristics to produce fresh and mild acid taste like yogurt and cheese. ${ }^{16,17}$

\section{Lactic Acid Bacteria with health stimulating property}

Due to the health property of fermented milk and milk products it became highly consumed with high demand (Table 2). Through several mechanisms, fermentation of milk is contributing in human health. ${ }^{3}$ Certain strains of Lactic Acid Bacteria (LAB) like genera 
Lactobacillus are highly utilized for health promoting bacteria. ${ }^{18}$ activity, anti-hypertensive, calcium binding activity and anti-cancer. ${ }^{19}$

Certain Lactobacillus strains are believed to Show immune modulator

Table I The main Lactic Acid Bacteria associated with milk and milk product fermentation

\begin{tabular}{|c|c|c|}
\hline Species/ Subspecies & Their main uses in different milk product & References \\
\hline \multicolumn{3}{|l|}{ Lactococcus } \\
\hline Lc. Lactic subsp. lactis & Mesophilic starter used for many cheese types, butter and butter milk. & $\begin{array}{l}\text { Broome et al. (2003) \& } \\
\text { Wouters et al. }{ }^{8}\end{array}$ \\
\hline $\begin{array}{l}\text { Lc. lactis subsp. actis biovar } \\
\text { diacetylactis }\end{array}$ & Used in Gouda, Edam, Sour cream and lactic butter and butter milk. & $\begin{array}{l}\text { Wood( } 1997) \text {, Leroy \& De } \\
\text { Vusyt (2004) }\end{array}$ \\
\hline \multicolumn{3}{|l|}{ Streptococcus } \\
\hline Sc. thermophilus & $\begin{array}{l}\text { Thermophilic starter used for yogurt and many cheese types' particularly hard } \\
\text { and semi hard high-cook cheeses. }\end{array}$ & $\begin{array}{l}\text { Broome et al. }(2003) \& \\
\text { Beresford et al. }(2001)\end{array}$ \\
\hline \multicolumn{3}{|l|}{ Lactobacillus } \\
\hline Lb. delbrueckii subsp. bulgaricus & $\begin{array}{l}\text { Thermophilic starter for yogurt and many cheese types, particularly hard and } \\
\text { semi-hard high-cook cheeses. }\end{array}$ & Salaterry et al. $(2010)$ \\
\hline Lb. delbrueckii subsp. lactis & Used in fermented milks and high-cook cheese. & $\begin{array}{l}\text { Broome et al. (2003) \& } \\
\text { Giraffa }^{26}\end{array}$ \\
\hline Lb. helveticus & & $\begin{array}{l}\text { Broome et al. }(2003) \& \\
\text { Griffith \& Tellez }\end{array}$ \\
\hline Lb. casei & $\begin{array}{l}\text { Thermophilic starter for fermented milks and many cheese types, particularly } \\
\text { hard and semi hard high-cook. }\end{array}$ & Briggs (2003), Kongo' ${ }^{16}$ \\
\hline Lb. plantarum & $\begin{array}{l}\text { Probiotic milk and cheese ripening adjunct culture. Cheese ripening adjunct } \\
\text { culture. }\end{array}$ & Leroy \& De Vuyst (2004) \\
\hline Lb. rhamnosus & Probiotic adjunct culture used in cheese. & Coppola et al. (2005) \\
\hline \multicolumn{3}{|l|}{ Leuconostoc } \\
\hline
\end{tabular}

Lb, Lactobacillus; Lc, Lactococcus; Ln, Leuconostoc; Sc, Streptococcus; subsp, Subspecies.

Table 2 Health benefits when milk is fermented

\begin{tabular}{|c|c|c|}
\hline Effect of fermentation & Changes in milk & Effect on health \\
\hline \multirow{4}{*}{$\begin{array}{l}\text { Increase in Lactic Acid } \\
\text { Bacteria levels }\end{array}$} & \multirow{4}{*}{$\begin{array}{l}\text { Reduced lactose contents in milk Reduced content } \\
\text { of bad bacteria }\end{array}$} & No diarrhea and bloating \\
\hline & & Improved gut health \\
\hline & & $\begin{array}{l}\text { Prevention of protection from bacterial vaginosis and } \\
\text { fungal infections in women }\end{array}$ \\
\hline & & $\begin{array}{l}\text { Ability to digest remaining lactose in the fermented } \\
\text { milk and use as energy source }\end{array}$ \\
\hline \multirow{5}{*}{$\begin{array}{l}\text { Breakdown to shorter } \\
\text { chain proteins }\end{array}$} & \multirow{5}{*}{$\begin{array}{l}\text { Identification of casein peptides and whey peptides } \\
\text { with functional properties }\end{array}$} & Easier digestion \\
\hline & & Some with anti-hypertensive effects \\
\hline & & Some with pain relief effects \\
\hline & & Some with immune enhancing properties \\
\hline & & Some with calcium binding bone building properties \\
\hline Increased acidity & Sharpness of taste & Prevents harmful bacterial growth in milk \\
\hline
\end{tabular}

Source: http://whqlibdoc.who.int/publications/2003/924I59| 196.pdf and ftp://ftp.fao.org/docrep/fao/007/y5686e/y5686e00.pdf 


\section{Lactic Acid Bacteria producing anti-microbial compounds}

During fermentation process Lactic Acid Bacteria (LAB) produces anti-microbial metabolites, include organic acids like propionic, acetic acid and lactic acids as final products. They create unfavorable environment to spoilage and pathogenic microorganism's growth. ${ }^{20}$ In habitory compounds includes Bacteriocins and hydrogen peroxide are against other bacteria. ${ }^{21}$ According to some studies LAB fermentation is preventing diarrheal diseases with the characteristics of changing composition of microorganisms in intestines. ${ }^{22} \mathrm{LAB}$ also produces Bacteriocins which are protein anti-microbial agents. ${ }^{23}$

\section{Functional starter cultures (role of Lactic Acid Bacteria)}

Application of LAB (Lactic Acid Bacteria) as starter strains in the manufacturing of different fermented milk products is very important. Particularly, L. lactis, L. helveticus, streptococcus thermophiles, $L$. delbruicki sub $s p$. The frequently used as milk starter cultures are bulgaricus. Yoghurt is made with L. bulgaricus and S. thermophilus and Lactococcus casei is found in cheeses. The manufacturer of milk fermented products needs to select proper and balanced amount of LAB used for starter cultures to make their desirable flavor and texture. ${ }^{24}$

\section{Lactic acid bacteria as preservative}

It is known that milk is perishable material. The normal milk can be kept stored just for few hours, while the Lactic acid Bacteria (LAB) fermented milk product can be stored for the whole year. Some variety of cheese can be stored for 5 years. Preservation of milk products with LAB fermentation is the cheapest technique. LAB has long history of consumption and application in cheese processing. ${ }^{25,26}$ The fermented food is more popular then unfermented according to consumers because of its organoleptic properties. It reduces $\mathrm{pH}$ below $4^{\circ} \mathrm{C}$ because of acid production and it stops pathogenic microorganism's growth. These microorganisms can produce disease and making milk spoiled. ${ }^{27}$

\section{Conclusion}

LAB's (Lactic Acid Bacteria) are gram positive organism used as starter cultures. S. thermophilus, L. helveticus, L. lactis and $L$. delbruckii subsp. bulgaricus are used mostly. In fermented foods LAB shows numerous anti-microbial roles because of production of organic acids. By producing Bacteriocins some strains are helpful in the fermented milk preservation. Milk fermentation is profitable due to decontamination of toxins, preservation and improving milk quality. Due to the good taste and texture it is also completing consumer expectations. Fermentation with LAB is also effective and cheap preservation method. It also improves nutritional value of milk products. This technology must be developed further to facilitate the ease and safety of application in poor rural resource setting.

\section{Acknowledgements}

None.

\section{Conflict of interest}

Author declares that there is none of the conflicts.

\section{References}

1. Panesar PS. Fermented Dairy Products: Starter Cultures and Potential Nutritional Benefits. Food Nutr Sci. 2011;2(1):47-51.

2. Liu SN, Han Y, Zhou ZJ. Lactic Acid Bacteria in Traditional Fermented Chinese Foods. Food Res Int. 2011;44(3):643-651.

3. Sharma R, Sanodiya BS, Bagrodia D, et al. Efficacy and Potential of Lactic Acid Bacteria Modulating Human Health. Int J Pharma Bio Sci. 2012;3(4):935-948.

4. Steele J, Broadbent J, Kok J. Perspective on the Contribution of Lactic Acid Bacteria to Cheese Flavour Development. Curr Opin Biotechnol. 2013;24(2):135-141.

5. Shah NP. Functional Cultures and Health Benefits. Int Dairy J. 2007; 17(11):1262-1277.

6. Ali A. Beneficial role of Lactic Acid Bacteria in food Preservation and Human Health: A review. Res J Microbiol. 2010;5(12):1213-1221.

7. Delavenne E, Mounier J, Deniel F, et al. Biodiversity of Anti-fungal Lactic Acid Bacteria Isolated from Raw Milk Samples from Cow, Ewe and Goat over One-Year Period. Int J Food Microbiol. 2012;155(3):185-190.

8. Wouters JTM, Ayad EHE, Hugenholtz J, et al. Microbes from Raw Milk for Fermented Dairy Products. Int Dairy J. 2002;12(2-3):91-109.

9. Ayad EHE, Nashat S, El-Sedek N, et al. Selection of wild Lactic Acid Bacteria isolated from traditional Egyptian dairy products according to production and technological criteria. Food Microbiol.2004;21(6):715-725.

10. Capice E, Fitzgerald GF. Food Fermentation: Role of Microorganisms in Food Production and Preservation. Int $J$ Food Microbiol. 1999;50(1-2):131-149.

11. Jay JM. Modern Food Microbiology. 6th ed. USA: An Aspen Pubication, Aspen Publishers, Inc. Gaithersburg; 2000:113-130.

12. Kuipers OP, Buist G, J Kok. Current Strategies for Improving Food Bacteria. Res Microbiol. 2000;151(10):815-822.

13. Moulay M, Benlancen K, Aggad H, et al. Diversity and Technological Properties of Pre-dominant Lactic Acid Bacteria Isolated from Algerian Raw Goat Milk. Adv Environ Biol. 2013;7(6):999-1007.

14. Yamina M, Wassila C, Kenza Z, et al. Physico Chemical and Microbiological Analysis of Algerian Raw Camel's Milk and Identification of predominating thermophilic Lactic Acid Bacteria. J Food Sci Eng. 2013;3:55-63.

15. Mayra-Makinen A, Bigret M. Industrial Use and Production of Lactic Acid Bacteria. In: Salminen S, Von Wright A, Ouwehands A, editors. Lactic Acid Bacteria. Microbiological and Functional Aspects. New York: Marcel Dekker, Inc; 2004:175-198.

16. Kongo JM. Lactic Acid Bacteria as Starter-Cultures for Cheese Processing: Past, Present and Future Developments. 2013.

17. Griffith MW, Tellez AM. Lactobacillus helveticus: The Proteolytic System. Front Microbiol. 2013;4:30.

18. Saxelin M, Tynkkynen S, Mattila-Sandholm T, et al. Probiotic and Other Functional Microbes: from Markets to Mechanisms. Curr Opin Biotechnol. 2005;16(2):204-211.

19. Nouaille S, Ribeiro LA, Miyoshi A, et al. Heterologous Protein Production and Delivery Systems for Lactococcus Lactis. Genet Mol Res. 2003;2(1):102-111.

20. Rattanacaikunsopon P, Phumkhachorn P. Lactic Acid Bacteria: Their Anti-Microbial Compounds their Uses in Food Production. Ann Biol Res. 2010;1(4):218-228. 
21. Oyewole OB. Lactic Fermented Foods in Africa and their Benefits. Food Control. 1997;8(5-6):289-297.

22. Schnurer J, Magnusson J. Anti-Fungal Lactic Acid Bacteria as Bio Preservatives. Trends Food Sci Technol. 2005;16(1-3):70-78.

23. Carolissen-Mackay V, Arendse G, Hasting JW. Purification of Bacteriocins of Lactic Acid Bacteria: Problems and Pointers. Int J Food Microbiol. 1997;34(1):1-16.

24. Derek AA, Joost VDB, Inge MKM, et al. Anaerobic Homolactate Fermentation with Saccharomyces Cerevisiae Results in Depletion of ATP and Impaired Metabolic Activity. FEMS Yeast Res. 2009;9(3):349-357.
25. Aquilanti L, Dell'Aquila L, Zannini E, et al. Resident Lactic Acid Bacteria in Raw Milk Canestrato Pugaliese Cheese. Lett Appl Microbiol. 2006;43(2):161-167.

26. Giraffa G, Chanishvili N, Widyastuti Y. Importance of Lactobacilli in Food and Feed Biotechnology. Res Microbiol. 2010;161(6):480-487.

27. Ananou S, Maqueda M, Martinez-Bueno M, et al. Biopreservation, An Ecological Approach to Improve the Safety and Shelf-Life of Foods. FORMATEX. 2007:1-12. 